\title{
Analisis Kelebihan dan Kekurangan dalam Pembelajaran Daring di SDN Pesanggrahan 01 Kota Batu Malang
}

\author{
Diterima: \\ 3 Juni 2021 \\ Revisi: \\ 27 Juli 2021 \\ Terbit: \\ 1 Februari 2022
}

\author{
Irfan Nurkholis \\ SDN Pesanggrahan 01 Kota Batu Malang \\ Malang, Indonesia \\ E-mail:irfan.nurkholism@gmail.com
}

\begin{abstract}
Abstrak- Pandemi covid-19 yang semakin tidak terkendali penyebarannya, mengakibatkan pembelajaran yang selama ini berlangsung secara normal menjadi terganggu. Pemerintah dipaksa mengambil langkah dalam proses pendidikan dengan melaksanakan pembelajaran secara online (daring) dari rumah. Pembelajaran secara daring adalah salah satu alternatif yang diharapkan dapat mengatasi masalah tersebut. Disisi lain sistem pembelajaran ini menuntut siswa memiliki fasilitas yang tepat guna mendukung pembelajaran yang sesuai. Tujuan penelitian adalah untuk memperoleh gambaran kelebihan dan kekurangan pembelajaran daring yang dilaksanakan di SDN Pesanggrahan 01 Kota Batu. Berdasarkan data di lapangan penggunaan teknologi belum maksimal dilihat dari beberapa kondisi guru yang berusia lanjut. Kondisi lain, masih banyak siswa yang tidak memiliki gawai untuk mengikuti pembelajaran daring karena ekonomi atau orangtua yang bekerja sepanjang hari. Metode penelitian yang digunakan adalah pendekatan kualitatif dengan jenis penelitian deskriptif. Responden yang digunakan sebagai data penelitian sebanyak 14 tenaga pendidik. Dari hasil penelitian ini dapat disimpulkan bahwa kelebihan pembelajaran daring lebih banyak dibandingkan kekurangannya. Inovasi dan perbaikan pembelajaran diperlukan untuk meningkatkan kualitas pendidikan.
\end{abstract}

Kata Kunci - pembelajaran, daring, kelebihan, kekurangan

Abstract - The COVID-19 pandemic, which is increasingly out of control, has disrupted learning that had been taking place normally. The government is forced to take steps in the education process by implementing online learning from home. Online learning is one alternative that is expected to overcome this problem. On the other hand, this learning system requires students to have the right facilities to support appropriate learning. The purpose of the study was to obtain an overview of the advantages and disadvantages of online learning carried out at SDN Pesanggrahan 01 Batu City. Based on data in the field, the use of technology has not been maximized, seen from the conditions of elderly teachers. Another condition is that there are still many students who do not have a smartphone to take part in online learning because of the economy or their parents who work all day. The research method used is a qualitative approach with descriptive research type. Respondents used as research data were 14 educators. From the results of this study, it can be concluded that the advantages of online learning are more than the disadvantages. Innovation and improvement of learning is needed to improve the quality of education.

Keywords - learning, online, advantages, disadvantages 
PTK, Vol.2 No.2 2022

ISSN: 2747-1977 (Print) / 2747-1969 (Online)

DOI: https://doi.org/10.53624/ptk.v2i2.45

\section{PENDAHULUAN}

Akibat yang cukup signifikan dari wabah coronavirus disease 2019 (COVID-19) yang disebabkan oleh Severe Acute Respiratory Syndrome Coronavirus-2 (SARS-CoV-2) telah membuat segala aspek kehidupan mengalami perubahan rutinitas (Susilo 2020). Pandemi covid19 berpengaruh terhadap berbagai aspek kehidupan khususnya dunia pendidikan di Indonesia (Darmuki 2020; Hidayati and Darmuki 2021). Kegiatan belajar mengajar di sekolah yang merupakan tempat interaksi siswa dan guru harus berhenti secara tiba-tiba. Pemerintah membuat kebijakan baru demi pencegahan penyebaran virus COVID-19 yaitu mengimplementasikan ajakan masyarakat untuk melaksanakan program physical distancing yang dinamakan dengan new normal era (Jamilah 2020). Selama masa new normal era, sebagian besar masyarakat Indonesia telah berusaha menjalani kehidupan baru dalam dunia pendidikan, termasuk sistem pembelajaran yang semestinya dilakukan secara langsung dan bermakna sekarang hanya dapat dilakukan secara mandiri. Dengan begitu peserta didik melakukan pembelajaran tidak langsung dengan memanfaatkan pembelajaran dalam jaringan atau daring yang dirasa cukup tepat guna di situasi seperti saat ini (Handarini and Wulandari 2020).

Belajar adalah suatu proses perubahan tingkah laku akibat dari pengalaman (Darmuki 2020). Belajar merupakan suatu proses perubahan tingkah laku yang membutuhkan dorongan atau motivasi untuk menggerakkan ke arah lebih baik, dari tidak bisa menjadi bisa, dari tidak tahu menjadi tahu (Darmuki et al. 2017). Perubahan tingkah laku tersebut bisa berupa dari aspek kognitif, afektif, maupun psikomotorik (Darmuki et al. 2017; Hidayati et al. 2020). Belajar juga dapat didefinisikan sebuah proses dimana tingkah laku ditimbulkan/berubah melalui latihan dan pengalaman (Hariyadi and Darmuki 2019). Mengajar adalah menanamkan pengetahuan pada peserta didik untuk mencapai tujuan yang telah ditetapkan (Darmuki and Hidayati 2019; Hidayati 2020). Kegiatan Belajar Mengajar (KBM) adalah suatu proses interaksi antara peserta didik dengan pendidik dan sumber belajar pada suatu lingkungan belajar (Darmuki dkk., 2017; Darmuki dkk., 2018; Darmuki et al. 2019; Hidayati et al. 2020). KBM merupakan bantuan yang diberikan pendidik agar dapat terjadi proses pemerolehan ilmu dan pengetahuan, penguasaan kemahiran dan tabiat, serta pembentukan sikap dan kepercayaan pada peserta didik sehingga peserta didik tumbuh dan berkembang dengan baik (Darmuki and Hidayati 2019; Darmuki and Hariyadi 2019). Hal ini sesuai dengan pernyataan Hidayati and Darmuki (2021) yang mengemukakan bahwa KBM adalah suatu proses persiapan yang dipersiapkan oleh guru guna menarik dan memberi informasi kepada siswa, sehingga dengan persiapan yang dirancang oleh 
guru dapat membantu siswa dalam mencapai tujuan pembelajaran dengan maksimal. Tujuannya adalah penguasaan pengetahuan, keteterampilan dan pemahaman oleh peserta didik.

Sejumlah sekolah menerapkan sistem belajar online atau virtual tanpa tatap muka langsung dari rumah masing-masing (study from home). Meski disinyalir menjadi keluhan bagi sebagian masyarakat dengan ekonomi ke bawah, serta tinggal di pelosok. Keterbatasan sarana dan prasarana, terpenuhinya layanan data dan jaringan merupakan faktor yang cukup penting. Pemilihan metode pembelajaran yang tepat juga akan mempengaruhi suasana belajar yang menyenangkan dan memungkinkan siswa untuk mengembangkan kreatifitas.

\section{METODE}

Metode penelitian merupakan cara yang digunakan peneliti dalam mengumpulkan data penelitiannya. Dengan menggunakan metode penelitian dapat diketahui hubungan yang signifikan antara variabel yang diteliti dan memperjelas gambaran tentang objek yang diteliti. Menurut Sugiyono (2017), metode penelitian pada dasarnya merupakan cara ilmiah untuk mendapatkan data dengan tujuan dan kegunaan tertentu. Metode penelitian yang digunakan adalah metode penelitian deskriptif dengan pendekatan kuantitatif. Metode penelitian deskriptif ini dilakukan untuk mengetahui keberadaan variabel mandiri, baik hanya pada satu variabel atau lebih (variabel yang berdiri sendiri atau variabel bebas) tanpa membuat perbandingan itu sendiri dan mencari hubungan variabel lain (Sugiyono 2017).

Dalam penelitian ini metode deskriptif digunakan untuk mengetahui kelebihan dan kekurangan pembelajaran daring. Data yang dikumpulkan dalam penelitian ini berupa data dari angket yang disebarkan kepada pendidik SDN Pesanggrahan 01 Batu. Subjek penelitian yang dilakukan ini terdiri dari 14 tenaga pendidik. Penelitian ini bertujuan menentukan sesuatu objek yang diteliti maka analisis yang dibutuhkan cukup dengan menggunakan persentase dengan perhitungan menggunakan rumus sebagai berikut:.

$\mathrm{P}=\mathrm{F} / \mathrm{N} \times 100 \%$

P: Jawaban Persentase

F: Jumlah Jawaban responden

$\mathrm{N}$ : Jumlah sampel

Memberikan interpasi terhadap presentase yang telah diperoleh dengan menggunakan rumus mean dengan perhitungan sebagai berikut:

$\mathrm{M}=(\Sigma(\mathrm{Fi} \times \mathrm{Xi})) / \Sigma \mathrm{Fi} \times 100 \%$

$\mathrm{M}$ : mean atau nilai rata-rata

Fi : jawaban frekuensi

PTK: Jurnal Tindakan Kelas | Hal:143-148 
PTK, Vol.2 No.2 2022

ISSN: 2747-1977 (Print) / 2747-1969 (Online)

DOI: https://doi.org/10.53624/ptk.v2i2.45

Xi : jawaban pilhan skor

Untuk mengetahui tingkat efektifitas dan efisiensi dari metode pembelajaran daring yang diaplikasikan selama pandemi oleh guru-guru SDN Pesanggrahan 01 Batu dikelompokkan berdasarkan hasil angket yang telah diberikan kepada guru. Hal ini dilakukan dengan tujuan untuk mengetahui kelebihan dan kekurangan menggunakan metode pembelajaran daring.

\section{HASIL DAN PEMBAHASAN}

Berikut ini adalah diagram hasil presentase kelebihan dan kekurangan menggunakan metode pembelajaran daring dengan responden guru:

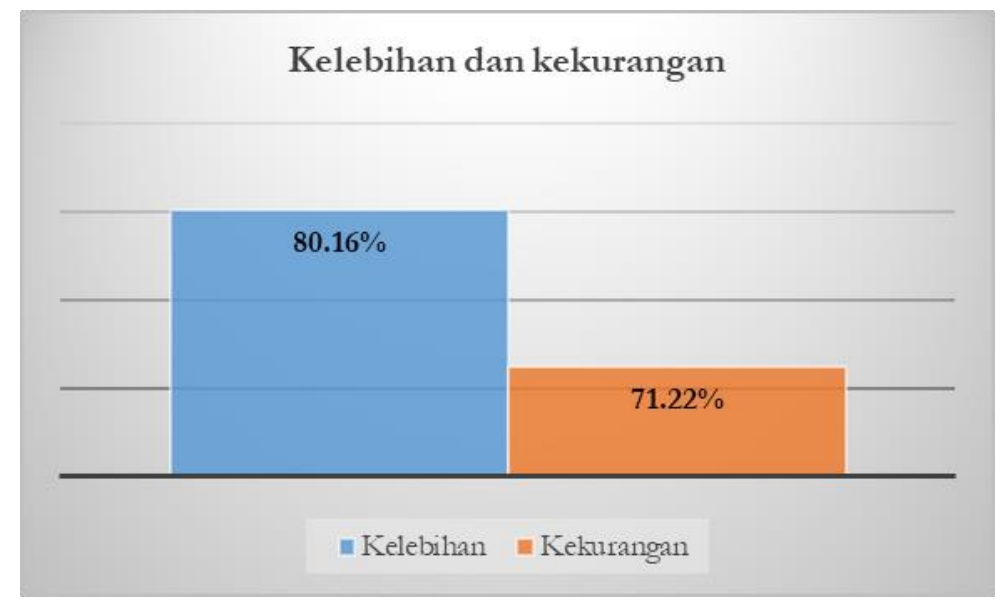

Gambar 1. Diagram Batang Hasil Presentase Kelebihan dan Kekurangan Menggunakan Metode Pembelajaran Daring

Dari diagram presentase tersebut dapat diketahui bahwa kelebihan pembelajaran daring mendapat nilai rata-rata 3,14 dengan persentase $80,16 \%$ sedangkan kekurangan pembelajaran daring mendapatkan nila rata-rata 2,55 dengan persentase $71,22 \%$.

Data hasil pengolahan di atas berdasarkan aspek-aspek yang telah ditentukan. Berikut ini penilaian dari masing-masing aspek:

1. Aspek Sarana dan Prasarana

Aspek Sarana dan Prasarana mendapat nilai presentase kelebihan proses pembelajaran secara daring sebanyak $80,24 \%$ dan kekurangan pada proses pembelajaran secara daring sebanyak $70,74 \%$.

2. Aspek Sumber Daya Manusia 
Aspek Sumber Daya Manusia mendapat nilai presentase kelebihan proses pembelajaran secara daring sebanyak $82,24 \%$ dan kekurangan pada proses pembelajaran secara daring sebanyak $80,02 \%$.

3. Aspek Karakteristik Pengajar dan Siswa

Aspek Karakteristik Pengajar dan Siswa mendapat nilai presentase kelebihan proses pembelajaran secara daring sebanyak $75,72 \%$ dan kekurangan pada proses pembelajaran secara daring sebanyak $72,62 \%$.

4. Aspek Jaringan (Network) dan Kuota

Aspek Jaringan (Network) dan Kuota mendapat nilai presentase kelebihan proses pembelajaran secara daring sebanyak $84,28 \%$ dan kekurangan pada proses pembelajaran secara daring sebanyak 76,23\%.

5. Aspek Kebijakan Pemerintah

Aspek Kebijakan Pemerintah mendapat nilai presentase kelebihan proses pembelajaran secara daring sebanyak $77,45 \%$ dan kekurangan pada proses pembelajaran secara daring sebanyak $75,22 \%$.

\section{KESIMPULAN}

Dari penelitian yang dilakukan, dapat ditarik kesimpulan bahwa pembelajaran daring memiliki banyak kelebihan dan kekurangan. Dari hasil penelitian ini, dilihat dari respon guru menunjukkan bahwa sistem pembelajaran ini memiliki dengan rata-rata kelebihan 3,14 dan ratarata kekurangan 2,55. Disimpulkan bahwa kelebihan pembelajaran daring lebih tinggi dari pada kekurangannya. Dalam pembelajaran seperti ini perlu adanya inovasi dan perbaikan-perbaikan secara continue untuk menunjang kualitas pembelajaran yang lebih baik.

\section{DAFTAR PUSTAKA}

Darmuki, A. \& Ahmad Hariyadi. (2019). Eksperimentasi Model Pembelajaran Jucama Ditinjau Dari Gaya Belajar Terhadap Prestasi Belajar Mahasiswa Mata Kuliah Berbicara Di Prodi PBSI IKIP PGRI Bojonegoro. Kredo. 3(1), 62-72.

Darmuki, A. \& Hidayati N.A. (2019). An Investigation of The Cooperative Learning Using Audio Visual Media in Speaking Skill Subject. ICSTI. 121-126.

Darmuki, A. \& Hidayati, N.A. (2019). Peningkatan Kemampuan Berbicara Menggunakan Metode Kooperatif Tipe NHT pada Mahasiswa Tingkat I-A Prodi PBSI IKIP PGRI Bojonegoro Tahun Akademik 2018/2019. Jurnal Pendidikan Edutama. Vol. 6(2), hlm 918.

Darmuki, A., Ahmad Hariyadi, Nur Alfin Hidayati. (2020). Peningkatan Minat dan Hasil Belajar Keterampilan Berbicara Menggunakan Metode Mind Map pada Mahasiswa Kelas IA PBSI IKIP PGRI Bojonegoro Tahun Akademik 2019/2020. Kredo.

PTK: Jurnal Tindakan Kelas | Hal:143-148 
PTK, Vol.2 No.2 2022

ISSN: 2747-1977 (Print) / 2747-1969 (Online)

DOI: https://doi.org/10.53624/ptk.v2i2.45

Darmuki, A., Andayani, Joko Nurkamto, Kundharu Saddhono. (2017). Cooperative, Synectics, Darmuki, A., Andayani, Joko Nurkamto, Kundharu Saddhono. (2017). Evaluating Information-Processing-Based Learning Cooperative Model on Speaking Skill Course. Journal of Language Teaching and Reasearch. 8(1) pp. 44-51.

Darmuki, A., Andayani, Joko Nurkamto, Kundharu Saddhono. (2018). The Development and Evaluation of Speaking Learning Model by Cooperative Approach. International Journal of Instruction. 11(2), 115-128.

Darmuki, Agus. (2020). Upaya Meningkatkan Kemampuan Berbicara Mahasiswa Menggunakan Media Aplikasi Google Meet Berbasis Unggah Tugas Video Di Youtube Pada Masa Pandemi Covid-19. Jurnal Educatio FKIP UNMA, Vol 6(2),655-661.

Handarini, O. I. \& Wulandari, S. S. (2020). Pembelajaran Daring Sebagai Upaya Study From Home (SFH) Selama Pandemi Covid 19. Jurnal Pendidikan Adminitrasi Perkatoran, 8(3).

Hariyadi, A., Agus Darmuki. (2019). Prestasi dan Motivasi Belajar dengan Konsep Diri. Prosiding Seminar Nasional Penguatan Muatan Lokal Bahasa Daerah sebagai Pondasi Pendidikan Karakter Generasi Milenial. PGSD UMK 2019, 280-286.

Hidayati, N. A. (2020). Penerapan Metode Mind Map Berbasis Drill Untuk Meningkatkan Kemampuan Berbicara Mahasiswa di Prodi PBSI IKIP PGRI Bojonegoro . Jurnal Educatio FKIP UNMA, 6(2), 462-468.

Hidayati, N. A., \& Darmuki, A. (2021). Penerapan Model Auditory Intellectually Repetition (AIR) untuk Meningkatkan Kemampuan Berbicara Pada Mahasiswa . Jurnal Educatio FKIP UNMA, 7(1), 252-259.

Hidayati, N. A., Waluyo, H. J., Winarni, R., \& Suyitno. (2020). Exploring the Implementation of Local Wisdom-Based Character Education among Indonesian Higher Education Students. International Journal of Instruction, 13(2), 179-198. https://doi.org/10.29333/iji.2020.13213a

Jamilah. (2020). Guru profesional di era new normal: Review peluang dan tantangan dalam pembelajaran daring. Jurnal Pendidikan Dasar dan Pembelajaran, 10(2). http://doi.org/10.25273/pe.v10i2.7494

Sugiyono. (2012). Metode Penelitian Kuantitatif, Kualitatif dan R \& D.Bandung:Alfabeta. Metode Penelitian Kuantitatif, Kualitatif Dan R \&D.Bandung: Alfabeta.https://doi.org/10.1017/ CBO9781107415324.004.

Susilo. (2020). Coronavirus Disease 2019: Tinjauan Literatur Terkini. Jurnal Penyakit Dalam, 7(1). http://dx.doi.org/10.7454/jpdi.v7i1.415

Utami, P. S., \& Gafur, A. (2015). Pengaruh Metode Pembelajaran Dan Gaya Belajar Siswa Terhadap Hasil Belajar Ips Di Smp Negeri Di Kota Yogyakarta. Harmoni Sosial: Jurnal Pendidikan IPS, 2(1),97103. https:// doi.org/10.21831/hsjpi.v2i1.4622. 